\title{
Introduction: political affairs in the global domain
}

\section{Christina Garsten and Adrienne Sörbom}

\section{INTRODUCTION: THE POLITICAL TURN OF BUSINESS}

This book sets out to investigate the manifold ways in which corporate actors attempt to influence political activities in the broad sense, in other words activities aimed at influencing the development of society. It brings together scholars from different fields in the study of global governance, to address the rising influence and power of corporate actors on the political scene, at national and transnational levels. These questions are addressed throughout the book by way of illustrative cases demonstrating the various ways in which corporations pursue political activities in the broad sense and how they aim to influence policy. One by one and taken together the chapters present an understanding of how corporate governance is pursued and with what types of consequences.

Corporate ascendancy has emerged as a universal organizing principle in the contemporary world. Corporations, and their funded offsprings, appear as both heroes and villains in tales of political and policy change. Proponents often present them as the 'new', responsible kind of corporate actors that global politics need, building networks across national borders and contributing to multi-stakeholders' solutions to complex issues. Sceptics view them as cunning organizations, barely masking their financial interests behind a thin layer of social and political concern. Both camps, however, would not deny the fact that corporate influence in what was usually seen as a nation-state domain of political affairs, have gained tremendous leverage over the last few decades. Through vast ideological shifts in the late twentieth century, markets rather than governments came to be seen as the more effective governance and the road to prosperity. Governments came to seek out the managerial expertise, technology and investment resources that corporations can bring. The corporate social responsibility movement (CSR) expresses this contemporary and double image of the corporation, as both a potentially accountable 'corporate 
citizen', capable of regulating and overseeing its own activities and as a profit-seeking, expansionist exploiter of human and natural resources. On both accounts, the political dimension of the corporation and of CSR is highlighted (Scherer and Palazzo 2011; Vallentin and Murillo 2012).

We are witnessing what we may term the political turn of corporations. Whilst corporations have always aimed to exert a degree of influence on the political infrastructures in which they operate and on decisions pertaining to regulatory frameworks, this trend has lately been intensified. With the restructuring of the provision of welfare services, and the accumulation of private capital, opportunities for corporations to influence political affairs have multiplied (Barley 2010; Sklair 2001). In recent decades we have seen an increase in corporate activities aiming to influence policymakers' perceptions of a particular problem, as well as the institutional arrangements in which they conduct their business (Lawton et al. 2012). Corporations have gained increased influence in certain policy areas and broadened their influence onto other policy areas usually under public control. A wide variety of firms are now involved in political activities in industries as varied as oil and gas, air transport, information technology, tobacco and pharmaceuticals. There are as well high levels of corporate participation in political fields such as energy and environmental policy, transportation, education and health care at national levels (see for example, Braithwaite and Drahos 2000). Influence is exercised by a variety of means, such as political campaign contributions, lobbying with policymakers, interlocking of board memberships, setting up political action committees (PACs), by providing analyses and research, creating standards for social responsibility and transparency and, at times, even by way of bribery (see for instance Austen-Smith and Wright 1996; Delmas and Montes-Sancho 2010; Hansen and Mitchell 2000; Okhmatovskiy 2010; Ring et al. 1990; Spiller 1990; Yoffie and Bergenstein 1985). Corporations have been able to amplify their influence as not merely implementers of public policy, but as agenda-setters and co-authors of policy. Furthermore, the resources at the command of corporations to do so are more powerful than ever. Yet, this development has hitherto not gained the attention it deserves.

Relations between what is commonly perceived as the spheres of politics and business are dynamic and complex, and corporations stand in a dynamic and complex relation to politics and policy. Oftentimes, corporations are analysed as separate from political institutions, practices and visions; as dependent on them; as creatively responsive to them; or, as is often the case, as antagonistic to them. As Neil Fligstein $(2001$, p. 6) maintains, however, ' $[t]$ he frequently invoked opposition between governments and market actors, in which governments are simply viewed as intrusive and inefficient, 
and firms as efficient wealth producers, is simply wrong. Firms rely on governments and citizens for making markets.' In other words, to 'make markets' and to pursue their interests, corporations rely on appropriate political and regulatory structures, for which they need to organize accordingly. The scope of corporate influence in politics and policymaking varies with time and space. Irrespective of scope, corporate political activity is central for the organization of markets (Ahrne et al. 2015).

Globalization processes have made it both possible and necessary for corporations and corporate-funded organizations to act politically outside the nation-state arena. The extensive movement in favour of marketdriven approaches to stimulate growth and improve living and working conditions put in place since the late 1970s has leveraged transnational corporations as legitimate actors with a part to play in an emerging system of global governance. Some of the big global questions, such as climate, forced migration, unemployment and threats to security, are now conceptualized as demanding transnational forms of collaboration into which corporations are often invited. A case in point is the G20 meetings, at which the role of business leadership in promoting and strengthening an open global market economy is now recognized to be central. Thus, large transnational corporations, such as The Evian Group, are invited to be part of deliberations. Another kind of arena for the fostering of interactions of state and non-state actors is the Club of Rome, a global think tank that deals with a variety of international political issues. Founded in 1968 at Accademia dei Lincei in Rome, Italy, the Club of Rome describes itself as 'a group of world citizens, sharing a common concern for the future of humanity'. It consists of current and former heads of state, UN bureaucrats, high-level politicians and government officials, diplomats, scientists, economists and business leaders from around the globe, convening to sort out issues of the contemporary state of affairs. One of its projects, to only give one example of the intersection of politics and corporations it constructs, regards 'circular economy', looking at the impact of a circular economy on jobs, carbon emissions and the trade balance in five different European economies, namely Finland, Sweden, France, the Netherlands and Spain. The results from the project were presented in front of the European Commission in October 2015 as an input to for the European Commission's package on Circular Economy, arguing that in all five countries, an economy based on circular resource flows would create jobs, reduce carbon emissions and improve the trade balance (http://www.clubofrome.org/project/circular_economy_ and_societal_benefit/, accessed 3 July 2016). Another pertinent example is Microsoft Corporation, an organization whose financial assets override those of many nation-states. Some of the wealth accumulated by its 
founder, Bill Gates, has been channelled into the Bill and Melinda Gates Foundation, which is now one of the most resourceful foundations in the world. The foundation is in itself active globally in shaping policy agendas, for instance by being present at the meetings of the World Economic Forum, where it is given ample space to present its views and propositions before other world leaders, but it also sponsors think-tank based research and analysis which is drawn upon in wider political settings. Finally, the Foundation is commonly credited for eradicating malaria in Africa. In this way, Microsoft influences not only markets but also political institutions and organizations.

Corporate influence on the political arena is thus taking on new and powerful forms. Due to their financial and organizational resources and their structural importance to employment, economic growth and technological innovation, corporations are in a privileged position on the global arena compared to other actors. Corporate actors also benefit from a host of international regimes that prioritize policy objectives such as free trade and free investment flows over others such as sustainability. This is not to say, however, that corporate actors will always dominate policy processes or dictate outcomes. Other types of actors, mainly from civil society, are invited to the arenas. The standing of corporations in these settings are, however, a reflection of the varying sources of power available to different types of non-state actors and the relative strength of corporations. We may concur that the nature of global governance is shifting, and with it the balance between political actors. The articulation of transnational politics will depend on a number of aspects, such as the issue-specific circumstances and power resources brought into play, which may also benefit other nonstate organizational actors rather than businesses in certain circumstances. In a globalizing world, political processes and their outcomes are likely to be more open-ended than ever before (Cerny 2010).

The amplification of globalization thus brings to the fore and highlights the multifarious ways in which governments and market actors are interdependently configured. Research into these kinds of activities is becoming all the more urgent and complex, not least because the pursuit of competitive advantage through political means may be ethically problematic and challenge established democratic procedures. What does such corporate engagement at transnational scale mean in terms of shaping policy priorities and agendas? What are the predominant ways by which corporate actors shape the way policymakers and politicians frame urgent problems? What are the means by which they contribute to defining what is the 'right way' forward?

This volume addresses the dynamic, complex and often conflictual relation of corporations to policy and power. This relation is indeed a 
long standing one, but one that keeps transforming along with geopolitical trends, financial fluctuations and social priorities. The relation is thus a moving target with potentially wide ramifications that calls for a close examination. Our starting point is that any investigation of emerging forms of global governance must now take into account the significance of corporate actors. A number of crucial questions call for attention: What are the mechanisms used by corporations and corporate-funded organizations to exert influence in the political sphere? What are the resources upon which such actions are based? What are the scenarios aimed for by the political activities of corporate actors? How do corporations and corporate-funded organizations achieve legitimacy as political actors? And what are the future prospects for democracy and welfare, as profit-driven actors engage in pursuing their interests in the public domain?

\section{CORPORATE POLITICAL AFFAIRS AT LARGE}

In this volume we focus our attention on corporations or corporatefunded organizations acting at national or transnational level to influence politics and policy. We take a broad perspective on politics, as relations involving authority, power, and the struggle for the allocation of resources and rights, taking place in most areas of day-to-day life as well as those commonly termed politics. Common to the authors of this book is thus the view of politics in the broad sense and taking a processual view on politics, implying that it is the continuous construction of interests and priorities, and the continuous negotiation and struggle over definitions of reality that concerns us most. In all chapters, it is the processes through which organizations attempt to gain influence and construct authority, rather than the resulting decisions and structures, which are in the limelight. Moreover, as stated by Andrew Abbott (2016, p. 41), there is no fixed 'topology of politics', no fixed location in which politics is done. Contemporary politics may take place outside of established political localities, in the interstices of political structures and with unconventional actors involved. In other words, places may be others than administrative councils, state agencies and formal legislatures and actors may be of many different kinds: corporate leaders, think tanks experts, PR-consultants, as well as elected politicians and civil servants. We also share the conviction that politics, as a social force, may be seen as productive as well as destructive (Spencer 2007). Politics allow for the mobilization of collectivities, for the articulation of shared and conflictual interests and ultimately for social change. The destructive side of politics means that collectivities may be torn by struggles over resources and access to decision-making arenas, and 
it may hinder social change and development. We wish, in other words, to work with an expansive notion of politics, which gives weight to the meaning-making, performative and aspirational dimensions of politics, beyond the instrumental (compare with Spencer 2007).

Policy is intimately related to politics, broadly seen as the ways in which politics is articulated and implemented. As pointed out by Wedel et al. (2005, p. 31):

[i]n an ever-more inter-connected world, public policies, whether originating with governments, businesses, supranational entities, nongovernmental (NGOs), private actors, or some combination of these, are increasingly central to the organization of society. Policies connect disparate actors in complex power and resource relations and play a pervasive, though often indirect, role in shaping society.

Policy is not to be seen as produced by rational choice, measured by positivist models and transferred by straightforward diffusion. Such approaches tend to miss out the contestations over meaning negotiations and political struggles that are integral to policymaking. In contrast, policy processes are messy, socially produced and embedded in power hierarchies (Shore et al. 2011). A focus on policy as a 'connector' between diverse organizational actors is, we believe, a fruitful way to investigate emerging forms of governance, power and politics.

Our curiosity about corporations and their relation to politics and policy stems from an interest in the operations of power in contemporary society. We take inspiration from Nikolas Rose and Peter Miller's viewpoint (1992, p. 175) - that 'political power today is exercised through a profusion of shifting alliances between diverse authorities, to govern a multitude of facets of economic activity and social life.' The common political vocabulary, structured by differences between state and civil society, public and private, coercion and consent and the like, is no longer apt to characterize the diverse ways in which power is exercised in advanced liberal democracies at global level. To analyse these aspects of contemporary power, we need to relocate the state and the market and the concepts of politics and non-politics. Moreover, power is a complex matter, which, as stressed by Steven Lukes in the revised version of his now classic book, shall be seen as a capacity that is constructed and not something which actors have or have not. Power may or may not be exercised, and actors may or may not be powerful by satisfying others' interests (Lukes 2005, p. 12). Thus, the interesting aspect of power is not primarily over what corporations may be powerful, since that changes over time, but in what sense and by what means they create the capacity to make others follow their interests, however non-unified, conflicting and shifting these interests may be. This 
perspective serves as a launch pad for investigations into the operations of power across and among organizational spheres: the public, private and civil spheres - nationally and transnationally.

We conceptualize the profusion of shifting alliances between diverse authorities as part of a move towards new forms of global governance (Hall and Biersteker 2002; Scholte 2004; Rhodes 1996), more specifically as the development of new public domains in which the boundaries between spheres are not as clear (Ruggie 2004). In this transnational domain states are still highly important actors, but they are also devolving some of their authority to private actors, such as corporations, think tanks and policy institutes (Stone 2008). Characteristic for activities relating to the global domain is the relativization of the significance of national boundaries. Even if actors still have their base in a given geographical territory, their activities are not tied to that territory (compare with Scholte 1996; 2005). They are to be understood as transnational in their capacity to operate and influence beyond national borders. Compared to the political sphere of international relations, which rely on established institutional structures, actors and procedures, transnational relations are still in a state of formation, with structures still emerging, actors competing for space and influence among themselves, and procedures of often ad hoc, contingent or flexible character. This means that the boundaries of the global domain are somewhat permeable, offering opportunities for many different and capable actors to participate. Examples of such nonstate organizations are the World Economic Forum, Brookings Institute, Fairtrade International Organization for Standardization, Motorola, Standard \& Poor's, Transparency International and Freedom House. Conjunctly, they all testify to the fact that the regulation of social and political concerns is no longer the business of nation-states alone. The state has to share regulatory agency with other organizations, such as corporations, international governmental organizations and international nongovernmental organizations. Whilst these actors may not have the 'hard' power exercised by the State by way of legal frameworks and sanctions, they work by crafting and diffusing norms, standards, codes of conduct and by putting into work political programmes for the transformation of minds and actions (Djelic and Quack 2010; Djelic and Sahlin-Andersson 2006). In Saskia Sassens's terminology (2003), new organizational 'sites of normativity' are appearing on the global scene, with power and resources to influence, shape and fashion the thoughts and actions of others.

The new global political domain that these actors are constructing is multilayered (Sassen 2006). It involves local, regional, state and transnational operations alongside and intertwined with each other. It involves a partial disaggregation of states as governments into extensive 
transnational networks, linking state authorities with international institutions, international non-governmental organizations and transnational corporations. Due to increasing crossover partnerships, global governance is more fragmented, decentralized and diffuse compared to nation-state based governing (Josselin and Wallace 2001; Scholte 2005). Regulation of global financial flows and social impacts of global market operations takes place through multilateral consultations and coordination. Representatives of corporations may consult, negotiate and make decisions with representatives of state departments, international organizations and so on. Corporate actors have learnt to exploit the space between state agencies, international organizations and INGOs, contributing to ever more complex multi-stakeholder constellations. Diane Stone (2008, p. 24) describes global policymaking as consisting of 'multilevel and polycentric forms of public policy in which a plethora of institutions and networks negotiate within and between international agreements and private regimes have emerged as pragmatic responses in the absence of formal governance'.

This also implies that matters of accountability, transparency and responsibility often become acute (Garsten and Lindh de Montoya 2008; Hansen 2012; Hansen and Flyverbom 2015; Hood and Heald 2006; West and Sanders 2003). Demands for transparency and accountability are raised by a variety of actors. The question is whether and to what extent corporations will take on the rights and the social obligations that accrue to them as legal entities whose activities have far-ranging implications for social lives. Furthermore, we may ask how these activities will be rendered transparency and accountability. Looking beyond accountability and transparency demands, an equally urgent question is how and to what extent corporations and corporate-funded organizations are themselves the architects of regulatory frameworks and governance structures. It is from this topical question that the authors of this book investigate corporate political activities.

Earlier research, as for instance in the impressive work of James Braithwaite and Peter Drahos (2000) regarding global economic regulation has clearly shown the importance of corporations in globalization processes, as has Leslie Sklair in his analysis of what he terms 'the new transnational capitalist class' (Sklair 2001). From the perspective of political science and economics Karin Svedberg Helgesson and Ulrika Mörth (2013) also discuss the concept of corporate citizenship and the political role of corporations in contemporary politics, arguing that transnational corporations have increasingly gained authority in global governance in later decades. Annegret Flohr and colleagues (Flohr et al. 2014) in similar terms analyse the role of business, pointing to the importance of self-regulation in for instance socio-economic and environmental fields when business corpora- 
tions participate in the setting of norms. From a political economy perspective, Christopher May (2006) has explored the ways in which corporations affect the practices and structures of the global political economy, stressing the role of global governance for constraining the power of global corporations. Within anthropology, important contributions have been made by for example Catherine Dolan, who shows how corporate engagement in fair trade also turns into being a political affair (Dolan 2008; Dolan and Scott 2009). Tania Lee (2007) has demonstrated the wide-ranging impact of private interests in the domain of international development, which again points in the direction of a political influence. Significant contributions have also been made in the area of CPA, defined as the study of corporate attempts to shape government policy in ways favourable to the firm (Baysinger 1984) in disciplines such as strategic management, sociology, political science, economics and finance (see Hillman et al. 2004 for overview; Lux et al. 2011).

The current volume adds to these lines of earlier research in two main ways. First, as will be elaborated in the next section, by introducing the concept of corporate bricolage in the field of corporate political activities. The concept offers a nuanced perspective as to the ways in which policy influencing by corporations is attempted. Second, by offering a number of empirical, mainly ethnographical studies, of these activities. Even though ethnographic research regarding the relationship between business and politics do exist, there is still a great need for close up studies of how corporations mould their environments.

\section{CORPORATE BRICOLAGE}

In a general sense, and as outlined by Lawton et al. (2012), studies of corporate political activity have focused rather narrowly on how firms use their strategic political resources and capabilities to improve their profitability (McWilliams et al. 2002). However, a broader interest in how a corporation deploys its political resources in a concerted fashion to manage its political environment has attracted growing attention. The relevance of the 'endogenous context', in which the firm expects to be confronted by policy decisions, stakeholders, issues or actions within a non-market political system, has been emphasized (Kim and Prescott 2005). Facing an unpredictable exogenous context, the corporation must react to this anticipated policy context through effective use of its political resources (Capron and Chatain 2008). Corporate attempts to influence policy have long been channelled to influence state agencies and other relevant parties by direct use of its political resources. 
Corporate influence may also be shielded by the creation of new organizations that more directly work to influence policy on behalf of corporations (Barley 2010). Corporations may establish political action committees (PACs), lobby firms, think tanks or other kinds of issuefocused organizations that work to establish knowledge, frame problem perceptions and shape agendas. These shielding organizations, whilst often focused on particular problem areas or policy issues, may voluntarily or involuntarily bar insight into the character and extent of corporate influence. An example of an influential North American PAC is the National Beer Wholesalers Association Political Action Committee (NBWA PAC). This is the largest PAC in the licensed beverage industry. NBWA PAC represents nearly 3,000 licensed, independent beer distributors, who have operations in every state and congressional district across the United States. The organization works to strengthen and maintain the state-based system of alcohol regulation.

Other organizations that may indirectly funnel corporate influence are think tanks funded by corporate capital and/or foundation capital. In a general sense, think tanks are organizations that undertake research and advocacy on specific and often burning topics and are most often registered as non-profit organizations. The growth of think tanks across the world over the last few decades have meant enhanced possibilities and intensified attempts of influencing policy (Ricci 1993; Rich 2004; Smith 1991; Stone 2000). As noted by Andrew Rich (2004, p. 153), 'the work of think tanks can be important to an issue beginning years before it becomes a subject of debate among policy makers.' It may also fluctuate along the timeline of a policy process. And its real impact is more often than not very difficult to trace. Think tanks may as well depend on a large and varied portfolio of funders for their operations, which makes it difficult to trace the actual influence of a particular corporate funder. The Competitive Enterprise Institute (CEI), a free-market think tank founded in the US in 1984, stands out as an example of a corporate-funded think tank. CEI takes a significant portion of its funding from private corporations. As expressed by Tom Medvetz (2012, p. 127): ' . . . while CEI's directors would not likely embrace the label corporate think tank, neither do they make any secret of their ultimate purposes as advocates for corporate interests'. Another case in point, but with an entirely different structure and agenda, is the World Economic Forum, financed by 1,000 of the world's largest corporations (Pigman 2007; Garsten and Sörbom 2016). Incorporated as a non-profit foundation, the World Economic Forum aims to be 'an independent international organization committed to improving the state of the world by engaging business, political, academic and other leaders of society to shape global, regional and industry agendas' (http://www.weforum.org/content/ 
leadership-team, accessed 3 October 2013). At the meetings arranged by the Forum, industry leaders meet with leaders from for example the United Nations, the World Trade Organization, with prime ministers and presidents, as well as with leaders from major civil society organizations, including Bill and Melinda Gates and other characters with double roles. Discussions on core global issues with high government officials take place in meetings that are not publicly announced. The idea propelled by the Forum, as the organizer of these meetings, is that the solutions put forth at the discussions should be pursued in the local settings of the participants, which also occasionally happens.

Another example of such an endeavour in the global policy domain is the World Business Council on Sustainable Development (WBCSD). The council organizes 200 of the world's largest corporations, who, as the organization presents it, on a daily basis are in contact with 50 per cent of the entire world's population. Its aim is to put forth 'business solutions for a sustainable world' (wbcsd.org, accessed 2 September 2013). As Patricia Arnas at the council's Washington, DC office declares when we meet:

We are a global organization, we aim to work at the global level. We do global, not national, advocacy work. Not lobbying. This dictates who we are and who we partner with. Today we target mainly UN-types of organizations as the OECD, UNEP, UNDP, OECD and Clean Energy Ministerial. The types of policies we work on are general, to fit the global level. For example: policy on carbon, where we are claiming the need for a global prize on carbon. We are not picking a type of energy source, we are just saying that there should be a cost, and it should be global, and subsidies must be abandoned. We aim to address issues at a higher level, at a high level of generalizability. (Interview 2014)

The Council does work in tandem with INGOs, but it also works directly with its own member corporations in order to inspire them to take social responsibility. The WBCSD is always invited to the WEF annual meetings in Davos, and many of its members are also members of the WEF. In turn, these members may turn up as the firm that an institutional investor with a 'responsible' profile may choose to invest in. Or, the members of WBCSD will meet with a partner from Fairtrade International at a side event for a UN climate change meeting, set up by WBCSD and the International Emissions Trading Associations (IETA). IETA has in turn visited Davos and the WEF annual meeting and are members of a WEF task force working group on accelerated investments in low-carbon technologies. The intersections between the different organizations active here are plentiful. WBCSB is an organization that is moulding its environment (see Barley 2010), and explicitly so at a global level.

Unintentionally, we find that most of the organizations explored in the 
volume have, in one way or another, been in contact with World Economic Forum, by being part of their partially organized network. For example, Susan C. Schwab, a member of a Global Action Council at the WEF, is also a board member of Boeing. The FLO international strategic partner HIVOS is a regular attendee at WEF-meetings. Apart from being a WEF strategic partner, Google is commonly understood to set up the best party during the Davos week, when WEF participants are entering the village for its annual meeting. Participants from Atlas Transnational of course also take part in WEF-activities.

Bringing to mind knowledge production in this manner thereby also points to the existential phenomena of global bricolage. Just like the economic entrepreneur recombines and makes creative use of existing resources, capitalizing on the capacity to mobilize practical knowledge in a way that challenges general theoretical approaches (Baker et al. 2003), corporate actors involved in global governance mobilize by combining resources, social as well as economic. Policy bricolage, then - understood as a mix of disorderly processes and institutional reassemblages - is grounded in cultural political economy and explores a cobbling together of multiple kinds of self-organization in national blocs and is only loosely meshed as a mode of informal global governance (Mittelman 2013). Further, the bricolage approach offers a grammar, a way to examine the combination of spontaneity and international groupings without onesidedly emphasizing the former or the latter. It thus views this experimentation as glimmerings of potential modifications in ways to steer the global political economy.

Evoking the Claude Lévi-Strauss concept of 'the bricoleur' (1966) in the public policy domain we see these corporate actors as policy bricoleurs, as organizations with the capacity to act both as market actors and as political actors, putting together different resources in heterogeneous forms. In the sphere where markets and politics are brought together, the bricolage character of such organizations makes them agile enough to manoeuvre across and combine market and political interests. The organizations involved in political affairs are therefore finicky to define as either or. They can be important for markets, but they are also important for politics and they are certainly active in combining both types of activities. Depending on the context and the interest pursued, they perform as primarily market actors or political actors.

At the emic level organizations that are set up to exert political influence often describe themselves in ambiguous terms, being for instance simultaneously foundations, non-governmental organizations and think tanks. The WEF, for example, describes itself as simultaneously a foundation, a nonprofit organization, an international institution and a think tank. It may 
shift flexibly between positions and roles in markets and in political circles, thus moving readily on the grazing grounds of both corporations and politicians, speaking freely with corporate leaders as well as with high-level politicians. In the same vein, as Tom Medvetz (2012) describes think tanks, ambiguity is a resource for policy bricoleur successes. Less bound by clearly defined roles - compared to, for example, universities and governments - think tanks, NGOs, research institutes and other organizations such as these are able to more freely draw upon the former institutions as established sources of knowledge, hereby establishing themselves as policy intellectuals, doing the 'intellectual groundwork' (Medvetz 2012, p. 5), influencing how citizens and lawmakers perceive the world. As for example the technical or architectural bricoleur turns to the tools at hand, establishing a dialogue with her/him self, the policy bricoleur draws upon existing resources, asking new questions of them, and thereby making them into something that carries further the sign of credibility but with a partly new understanding of the content. These types of ambiguous organizations are not a particularly new phenomenon. What is new is the scale and political importance of the activities of these kinds of organizations. Both nationally and transnationally governance outside and in between governments are staged to an increasing, and unprecedented, level.

\section{PROFIT, POWER AND POLICY CLOSE UP}

As Stephen Barley contends (2010), organizational researchers have not been that interested in how corporations mould their environment. They have instead focused their attention on the internal affairs of corporations, less so on their outward interests. This pattern is true also for research based in other traditions and perspectives. Economists and sociologists with an interest in corporate political activity have analysed this in order to answer questions pertaining to why corporations may have an interest in funding politics, which corporations fund the most and their role vis-àvis governmental organizations (see for instance Boies 1989; Burris 2001; Hillman et al. 2004; Ronit 2001; Ronit and Schneider 1999; Hansen and Mitchell 2000). Political scientists, primarily interested in governmental activities, have had their prime interest in governmental politics and not corporate politics (Archer 2001; Stone 2012). The strands of research on international political economy stand out as exceptions (as seen in for example Braithwaite and Drahos 2000; Koppel 2010).

This book answers the criticism raised by Barley, and asks questions regarding corporations and their relation to politics. The relationship is old, but due to the scale and the increasing importance of these kinds of 
political affairs they call for a close examination. What kinds of activities do corporations pursue, in what forms, on what issues and with what solutions put forward? How do they achieve legitimacy as actors in the global political domain?

When looking for answers to these questions the policy bricolage concept invites us to look for empirical examples that reflect the flexibility and ambiguities in the organizational relations that these actors oftentimes display. Global rules for markets do emerge from intergovernmental organizations in the form of treaties and conventions. But they are also announced by non-governmental bodies, sometimes formed by corporations or in quasi-governmental forms where corporations in different forms are active together with other types of organizations, for example by issuing standards and/or recommendations (Koppel 2010, p. 8). The contribution of Power, Policy and Profit is to analyse some of these flex organizations in motion.

First, the volume presents a number of chapters that analyse corporate interests in shaping regulation. Mikkel Flyverbom in his chapter on advocacy by corporations, Christina Garsten and Adrienne Sörbom on the role of corporations in the World Economic Forum, Picard et al. on corporate governance and Anna Tyllström regarding lobbying consultancy, all give empirical insights as to the intermixing of corporate interests for policy, power and profit. Marie-Laure Salles-Djelic's chapter relates to this theme but from an interest for Atlas TI as the originator of neoliberal think tanks. Hervé Dumez and Alain Jeunemaitre's chapter focuses on how a large corporation attempts to cross the public-private sector divide, in order to create increased rents, thereby altering regulations of markets (for instance, who has the right to run schools).

Second, the volume also presents analyses of corporate interests in 'doing good', that is to say of business as prefigurative politics (compare Leach 2013). As for social movements, the fundamental idea here is to change the world by changing the means employed, internally in the company and externally for customers. The chapters by Renita Thedvall and Anette Nyqvist respectively, show how some corporations and financial institutions attempt to make money by doing the 'right thing', that is, by politicizing their activities. In the chapter by Bo Rothstein, however, the reversed idea is presented, when arguing for corporations being in need of non-market based ideology to control their activities.

\section{OUTLINE OF CHAPTERS}

Chapter 1, by Marie-Laure Salles-Djelic presents the role of Atlas Transnational, the mother of neoliberal think tanks. Over the last 40 
years or so, neoliberalism has become the 'new dominant regime of truth' (Burgin 2013; Djelic 2006) with a significant performative impact on national policymaking (Campbell and Pedersen 2001) as well as in regards to dynamics of transnational governance (Lee and McBride 2007). Of particular interest here is the carrier and boundary-spanning role of the dense ecology of neoliberal think tanks and research institutes that has come to be structured over the past four decades. These think tanks espouse a market- and business-friendly ideology and have made it their mission to champion, spread, defend and entrench, as widely and deeply as possible and in a multiplicity of contexts, this ideology and its associated politics. In the chapter, Salles-Djelic presents the historical dynamics of emergence of this dense ecology of neoliberal think tanks. Salles-Djelic explores the role of Atlas, that was created to 'litter the world' with free-market think tanks (Blundell 2001) with a particular interest for the process through which the organizational form of the 'neoliberal think tank' came to be constructed, diffused and progressively institutionalized during that period. Unpacking potent - albeit subtle and indirect - mechanisms of influence that have largely been neglected in the literature Salles-Djelic contributes to the understanding of the relationship between business and politics. As the chapter shows, neoliberal think tanks were constructed to shape and spread ideological, political and practice templates and to help crystallize and stabilize them across the world both in the corporate and in the political world.

Departing from an interest in the involvement of business leaders in the sphere of politics, in the broad sense, Christina Garsten and Adrienne Sörbom analyse the role of business within the World Economic Forum (WEF). Many global business leaders today do much more than engage narrowly in their own corporation and its search for profit, and the WEF is one such arena through which firms act through to advance their interests, financial as well as political. The organization has built its position and reputation on providing an arena for large-scale business corporations and top-level political elites, and the influence of corporations on the structure and content of activities should not be underestimated. The chapter indicates a number of conduits through which business may draw upon the WEF and its platforms as a strategically positioned amplifier for their non-market interests. However, the WEF cannot only be conceived as the extended voice of corporations. The WEF also makes use of the corporations to organize and expand its own agency, which doesn't necessarily coincide with the interests of multinational corporations. Garsten and Sörbom introduce the notion of policy bricolage in the chapter as a way to capture the ambiguous, creative and agile role of the WEF and its relation to corporations. By way of corporate financial resources, the 
tapping of knowledge and expertise and access to vast networks of business relations, the WEF is also able to amplify its own voice. On top, it is through the support and engagement of business, as well as that of political leaders and non-governmental high profiles, that the organization gets its spin. The global policy bricolage of the WEF is thus not just a complex form of global governance, but also an intricate system of interweaving market and political interests, and one that both amplifies and blurs the choir of voices.

Drawing the case of construction of the European carbon market (EUETS) Mélodie Cartel, Eva Boxenbaum, Franck Aggeri and Jean-Yves Caneill, in Chapter 3, address the question how public policies can be designed and implemented when facing strong reluctance from both politicians and private corporations? The EU-ETS was adopted in 2003 as the corner stone of the European climate policy. The authors analyse the collective dynamics of the making of the European carbon market. Based on a rich set of archival data and interviews, the analysis reconstitutes the original strategy deployed by the electricity sector to implement a carbon market in Europe. Empirically, the chapter shows that during the Kyoto Protocol, the European Commission opposed emissions trading, and the industrial companies pleaded against any measure involving a price on carbon. In spite of this reluctance, a handful of actors in the electricity sector believed that a carbon market could be an effective solution to manage carbon emissions at the company level. From 1999 to 2001, these actors organized two successive experiments where they invited industrial companies to build and test various carbon market prototypes. The chapter indicates that these experiments triggered an intellectual shift among participants and considerably fuelled the policymaking process that led to the EU-ETS.

The point of departure for Tyllström, in Chapter 4, is an interest in giving ethnographic evidence to lobbying, something that, in spite of the plethora of organizations devoted to political influence that has emerged globally since the 1970s, has been conspicuous by their absence (Barley 2010). Drawing on ethnographic fieldwork from the realm of public affairs consultancy, the chapter provides insights into the practical nature of corporate lobbying, as well as a discussion of how these consultants practice lobbying, and the role of lobbying may have in politics and markets. The case describes how a powerful industry player wishes to influence policy, hires a consultant who uses classical tools to gain political influence such as identifying key players and enemies, good arguments and counterarguments. As such, the case gives a rare account of how these tools are used by public affairs consultants. In generalized terms, the chapter shows the lobbying of public affairs consultants to revolve around five practices; information-gathering, contact management, visibility management, role- 
switching and ideological proactivity. These five types of practice are distinctly observable aspects of lobbying work, but they also feed into and amplify each other. Tyllström shows how the switching roles facilitates the establishment of contacts, which in turn enables the gathering of better, more valuable information. Furthermore, the constant management of boundaries between invisibility and visibility, the rich contact networks and the constant adjustment of identities together makes it possible for consultants to launch their own political ideas into the opinion landscape. Understanding these qualities of practice and how they interact is crucial to understanding the resurgent critique against lobbyism concerning its hidden nature and role confusion. As Tyllström concludes, fuzziness is not external to lobbying practices; it is at the heart of it.

In Chapter 5 Dumez and Jeunemaître analyse political strategies of firms, based on the case of Boeing from the late 1990s and early 2000s. The traditional view of firms' political strategies is that, by acting on the state, they will protect and expand firms' interests. But whereas in the classic game (to prevent the vote of an adverse law for example) corporate interests from the outset were seen as clearly defined, in the new game companies frequently are seen as identifying their interest in the course of actions and interactions with politicians (Woll 2008). The context of political action is often deeply uncertain. Therefore, the traditional opposition between market and non-market strategies, and between relational and transactional political activities should be questioned, especially in a period marked by globalization. Boeing's strategy in the late 1990s and early 2000s serves as an illustrating case of these tendencies. Boeing had been accustomed to traditional strategies of lobbying (for example in the context of its rivalry with Airbus) and financing political life. But in the late 1990s, it developed ambitious strategies aimed at building up influence rents. These strategies failed for Boeing, but analytically Dumez and Jeunmaitre are able to draw on the case for identifying new types of relationships between firms and the state.

Mikkel Flyverbom, in Chapter 6, sets out to expand the conception of corporate advocacy by pointing to the growing importance of knowledge, data and visualizations. Drawing on insights from the literature on the politics of knowledge (Rubio and Baert 2012) and the importance of knowledge in governance (Foucault 1980; Stone 2002) Flyverbom develops a conceptual entry point for enhancing the understanding of how Internet companies engage multiple forms of knowledge and visualizations as resources in their efforts to shape public perceptions, politics and regulation. To this end, the chapter uses illustrations from a study of Google and Facebook. Based on interviews with policy directors, participant observations in multi-stakeholder dialogues initiated 
by the UN, as well as documentary research, the chapter discusses the various forms of corporate advocacy that play out in this field. These prove to be: relationship building, message crafting and data provision. While the first two are well established, the focus on the provision of data, algorithms and technological platforms adds a new dimension to our understanding of corporate advocacy. This typology and the empirical illustrations serve as the basis for a conceptual and contextual embedding of visual numbers- and data-based forms of knowledge production and advocacy in relation to prevalent forms and understandings of corporate political activities.

Contrary to the earlier chapters, where focus has been on how firms and corporations attempt to diffuse their specific views and interests to other actors, the chapter 'Talking like an institutional investor: on the gentle voices of financial giants' (Chapter 7) by Anette Nyqvist, analyses how corporate actors attempt to relate to norms and scripts for taking social responsibility. Through analysing the talk of institutional investors Nyqvist describes and discusses some of the ways in which organizations with the primary goal of 'making money' increasingly also embark on projects of 'doing good'. Institutional investors, such as mutual funds, insurance companies and pension funds, are large shareholder organizations commissioned to manage other people's money. These have in later decades emerged as influential front figures of the responsible investment industry, claiming to make money and make a difference and positioning themselves as the 'active' and 'responsible' do-gooders of finance. Nyqvist sees them as intermediary organizations that in a relatively short time have grown in size and scope and now dominate corporate ownership globally. They are normative and fostering financial actors that aim to, in their view, better the way companies conduct their businesses. Nyqvist shows how institutional investors use 'voice', 'dialogue' and 'small talk' with the intent to (1) define and position themselves as a particular type of financial market actor, (2) foster and try to change companies that they own shares in and (3) set new standards for the investment industry.

In Chapter 8, Sébastien Picard, Véronique Steyer, Xavier Philippe and Mar Pérezts offer a broad vision of corporate political activities, highlighting its institutional reach, and describing its concrete institutionalizing effects. Drawing on Michel Lallement (2008) the authors attempt to open the black box of the institutionalization processes of corporate political activity and the institutional dynamics associated with this type of activity. Using data from an in-depth ethnography in VaxCorp, a leading corporation in the vaccine industry, the authors analyse how the company shapes its institutional field by imposing the dominant 'vaccinology' imaginary. In practice this takes shape in a modus operandi 
that goes beyond the mere maximization of VaxCorp's interests to organize actions and behaviours of other institutional actors (for example, State, WHO). The analysis indicates that this imaginary emerges from but also intertwines institutionalizing processes into a larger and coherent pattern, which eventually legitimizes corporations' dominance in an institutional field.

Renita Thedvall demonstrates in Chapter 9 the dynamics of standardization (Brunsson et al. 2012) when implementing fairtrade standards in a chocolate factory. What worldviews and ideals are embedded in Fairtrade International's standards? How are these worldviews and ideals negotiated and navigated in relation to economic issues of marketability as well as other political ideals present in the factory? The chapter gives ethnographic insights of the attempts of the long-established chocolate factory to develop a product in line with the fairtrade standard. Interestingly, the production process of conventional chocolate would be identical to the one following the standard. However, the purchase and storage of fairtrade raw material proved to be a challenge bringing attention to political concerns within the chocolate factory. In fact, the factory's choice to use an ethical label on one of its products brought a whole set of political discussions, as well as new priorities within the factory. The political in this context was not primarily the words and values in the fairtrade standards documents and certification criteria being implemented as part of the CSR strategy of the chocolate factory. Instead it was the fact that the fairtrade label, and its standards and compliance criteria, opened a space for politics in the chocolate factory. In this way, the words and the values in the standards documents and compliance criteria were translated and adjusted turning the fairtrade labelled products into a political affair matching the chocolate factory's political ideals. Still, the negotiated fairtrade ideals did not carve out a space for them in the milk chocolate segment. Thus, making a business out of being fairtrade opened a space for politics within the factory but not for business and the carefully chosen chocolate bar wrapping including the fairtrade label was discarded and wrapping papers without labels were put in the flowpack machine.

In the chapter authored by Bo Rothstein (Chapter 10), the focus is set on corporations, corruption and power, thus stressing the intersection between policy and markets. The analysis starts from the term 'legal corruption', coined by former leading World Bank economist Daniel Kaufmann. The term is to be understood as a problem of collective action, leading to a social trap, in which it makes no sense of acting legally when one does not know if other actors do too. As Rothstein argues, corruption is one important factor in explaining the financial crisis in 2008, and the main aim of the chapter is to present 
four interrelated arguments that sum up to a theory about the relation between the logic of markets, regulation and social efficiency. The first argument is that competitive markets are, hitherto, the most efficient organizational form of creating a utilitarian-based economic efficiency for the production of most goods and services. Second, Rothstein maintains that in order to reach this utilitarian-based efficiency, markets need a large and quite complicated set of institutions, formal as well as informal. The third argument, however, is that we have little reason to expect that such institutions will be created endogenously by agents acting from the standard self-interested utility-maximization template. This is because such efficient institutions are genuine public goods and therefore are prone to the well-known problem of collective action. Thus, as argued by Rothstein, contrary to what has been taken for granted by most policymakers in the area of financial regulation the implication is that we should expect market agents to act in a way that either will prevent efficient institutions to be established, or if they are established, will try to destroy them by various forms of 'free riding'. The fourth argument is, therefore, that markets can only reach social efficiency if the agents that have the responsibility to produce and reproduce the necessary institutions act according to a logic that is different from the logic that market agents use when operating in the market.

David Westbrook concludes the volume stressing the points of departure for the volume as a whole, the need for 'leaving flatland' in the analysis of relationships between markets and politics. In Flatland, the Victorian author Edwin Abbott told the story of a square, prosperously living in a society located (and understood) in a two dimensional plane, but challenged by a visitor in form of a sphere (Abbott 1884[1998]). Analogous to Flatland, we, the social scientists, tend to commonly address a complex fabric of relations with a very simple normative vocabulary: liberalism. Along the same lines as Abbott, Westbrook asks how we, from within the liberal plane, might conceive of the social, so that we might imagine politics in at least three dimensions? As Westbrook argues, the impoverishment of political discourse as it is commonly portrayed in social sciences may be unwise, even dangerous. Instead, Westbrook suggests that the social sciences, and anthropology in particular, can help to foster a more institutional, and more responsible, political imagination. While social science may still find itself constrained to present itself as a science, the inquiry at issue here is into collective subjectivity, and thus inherently interpretive, rather than objective. If the new science distinguished itself from its ancestors by abandoning teleology, it is precisely the reengagement with teleology that is urged here, not for the study of nature, but for the study of communities, with their constitutive norms. 


\section{REFERENCES}

Abbott, A. (2016), Processual Sociology, Chicago: Chicago University Press.

Abbott, E.A. (1884), Flatland: A Romance of Many Dimensions, in [1998], Penguin Classics.

Archer, C. (2001), International Organizations, New York: Routledge.

Ahrne, G., P. Aspers and N. Brunsson (2015), 'The organization of markets', Organization Studies, 36 (1), 7-27.

Austen-Smith, D. and J.R. Wright (1999), 'Theory and evidence for counteractive lobbying', American Journal of Political Science, 40, 543-64.

Baker, T., A.S. Miner and D.T. Eesly (2003), 'Improvising firms: Bricolage, account giving and improvisational competencies in the founding process', Research Policy, 32, 255-76.

Barley, S. (2010), 'Building an institutional field to corral a government: A case to set an agenda for organization studies', Organization Studies, 31 (6), 777-805.

Baysinger, B.D. (1984), 'Domain maintenance as an objective of business political activity: An expanded typology', Academy of Management Review, 9 (2), 248-58.

Blundell, J. (2001), 'Waging the War of Ideas, London: IEA', at http://www.iea. org.uk/sites/default/files/publications/files/upldbook226pdf.pdf. Accessed 3 July 2016.

Boies, J.L. (1989), 'Money, business and the state: Material interests, Fortune 500 corporations, and the size of political action committees', American Sociological Review, 54 (5), 821-33.

Braithwaite, J. and P. Drahos (2000), Global Business Regulation, Cambridge: Cambridge University Press.

Brunsson, N., A. Rasche and D. Seidl (2012), 'The dynamics of standardization. Three perspectives on standards in organization studies', Organization Studies 33 (5-6), 613-32.

Burgin, A. (2013), The Great Persuasion, Cambridge, MA: Harvard University Press.

Burris, V. (2001), 'The two faces of capital: Corporations and individualists as political actors', American Sociological Review, 66 (3), 361-81.

Campbell, J. and O. Pedersen (eds) (2001), The Rise of Neoliberalism and Institutional Analysis, Princeton, NJ: Princeton University Press.

Capron, L. and O. Chatain (2008), 'Competitors' resource-oriented strategies: Acting on competitors' resources through interventions in factor markets and political markets', Academy of Management Review, 33, 97-121.

Cerny, P.G. (2010), Rethinking World Politics: A Theory of Transnational NeoPluralism, Oxford: Oxford University Press.

Courpasson, D. and S. Clegg (2006), 'Dissolving the iron cages? Tocqueville, Michels, bureaucracy and the perpetuation of elite power', Organization 13, 319-43.

Delmas, M.A. and M.J. Montes-Sancho (2010), 'Voluntary agreements to improve environmental quality: Symbolic and substantive cooperation', Strategic Management Journal, 31, 575-601.

Djelic, M.L. and K. Sahlin-Andersson (eds) (2006), Transnational Governance, Institutional Dynamics of Regulation, Cambridge: Cambridge University Press.

Djelic, M.L. and S. Quack (2010), Transnational Communities: Shaping Global Governance, Cambridge: Cambridge University Press. 
Dolan, C. (2008), 'In the mist of development: Fair trade in Kenyan tea fields', Globalizations, 5 (2), 305-18.

Dolan, C. and L. Scott (2009), 'Lipstick evangelism: Avon trading circles and gender empowerment in South Africa', Gender and Development, 17 (2), 203-18.

Fligstein, N. (1996), 'Markets as politics: A political-cultural approach to market institutions', American Sociological Review 61, 656-73.

Fligstein, N. (2001), The Architecture of Markets: An Economic Sociology of Twenty-First Century Capitalist Societies, Princeton: Princeton University Press.

Flohr, A., L. Rieth, S. Schwindenhammer and K. Wolf (2014), The Role of Business in Global Governance, Corporations as Norm Entrepreneurs, Basingstoke: Palgrave Macmillan.

Foucault, M. (1980), Power/Knowledge: Selected Interviews and Writings 19721977, New York: Pantheon Books.

Garsten, C. and M. Lindh de Montoya (eds) (2008), Transparency in a New Global Order: Unveiling Organizational Visions, Cheltenham: Edward Elgar.

Garsten, C. and A. Sörbom (2014), 'Values aligned: The organization of conflicting values within the World Economic Forum', in S. Alexius and K. Tamm Hallström (eds) Configuring Value Conflicts in Markets, Cheltenham: Edward Elgar.

Garsten, C. and A. Sörbom (2016), 'Magical formulae for market futures: Tales from the World Economic Forum meeting in Davos', Anthropology Today, 32 (6), 18-26.

Hall, R.B. and T.J. Biersteker (2002), The Emergence of Private Authority in the International System, New York: Cambridge University Press.

Hansen, H.K. (2012), 'The power of performance indices in the global politics of anticorruption', Journal of International Relations and Development, 15 (4), 506-31.

Hansen, H.K. and M. Flyverbom (2015), 'The politics of transparency and the calibration of knowledge in the digital age', Organization, 22 (6), 872-89.

Hansen, W. and N. Mitchell (2000), 'Disaggregating and explaining corporate political activity: Domestic and foreign corporations in national politics', American Political Science Review, 94, 891-903.

Hillman, A.J., G.D. Keim and D. Schuler (2004), 'Corporate political activity: A review and research agenda', Journal of Management, 30 (6), 837-57.

Hood, C. and D. Heald (eds) (2006), Transparency: The Key to Better Governance? Oxford: Oxford University Press, pp. 3-23.

Josselin, D. and W. Wallace (eds) (2001), Non-State Actors in World Politics, Basingstoke: Palgrave.

Kim, B. and J.E. Prescott (2005), 'Deregulatory forms, variations in the speed of governance adaptation, and firm performance', Academy of Management Review, 30, 414-25.

Koppel, J.G.S. (2010), World Rule, Accountability, Legitimacy, and the Design of Global Governance, Chicago: University of Chicago Press.

Lallement, M. (2008), 'L'entreprise est-elle une institution? Le cas du Familistère de Guise', Revue Française de Socio-Economie, 1, 67-87.

Lawton, T., S. McGuire and T. Rajwani (2012), 'Corporate political activity: A literature review and research agenda', International Journal of Management Reviews, 15, 86-105.

Leach, D.K. (2013), 'Prefigurative Politics', The Wiley-Blackwell Encyclopedia of Social and Political Movements. DOI: 10.1002/9780470674871.wbespm167. 
Lee, S. and S. McBride (eds) (2007), Neo-Liberalism, State Power and Governance, Dordrecht: Springer.

Lee, T. (2007), The Will to Improve: Governmentality, Development, and the Practice of Politics, Durham: Duke University Press.

Lévi-Strauss, C. (1966), The Savage Mind, Chicago: Chicago University Press.

Lukes, S. (2005), Power: A Radical View, 2nd Edition, Basingstoke: Palgrave Macmillan.

Lux, S., T.R. Croock and D.J. Woehr (2011), 'Mixing business with politics: A meta-analysis of the antecedents and outcomes of corporate political activity', Journal of Management, 37 (1), 223-47.

Mandel, R. and C. Humphrey (eds) (2002), Markets and Moralities: Ethnographies of Post-socialism, Oxford/New York: Berg.

May, C. (2006), Global Corporate Power, International Political Economy Yearbook 15, Lynne Riener Publishers.

McGann, J.G. (2007), Think Tanks and Policy Advice in the United States. Academics, Advisors and Advocates, Oxon: Routledge.

McWilliams, A., D. Van Fleet and K. Cory (2002), 'Raising rivals' costs through political strategy: An extension of resource-based theory', Journal of Management Studies, 39, 707-23.

Medvetz, T. (2012), Think Tanks in America, Chicago: Chicago University Press.

Mittelman, J.H. (2013), 'Global bricolage: Emerging market powers and polycentric governance', Third World Quarterly, 34 (1), 23-37.

Okhmatovskiy, I. (2010), 'Performance implications of ties to the government and SOEs: A political embeddedness perspective', Journal of Management Studies 47, 1020-47.

Pattberg, P. (2005), 'The institutionalization of private governance: How business and nonprofit organizations agree on transnational rules', Governance 18 (4), 22.

Pigman, G.A. (2007), The World Economic Forum: A Multi-Stakeholder Approach to Global Governance, Abingdon: Routledge.

Rhodes, R.A.W. (1996). 'The new governance: Governing without government', Political Studies, 44 (4), 652-67.

Ricci, D. (1993), The Transformation of American Politics, The New Washington and the Rise of Think Tanks, Yale: New Haven University Press.

Rich, A. (2004), Think Tanks, Public Policy, and the Politics of Expertise, Cambridge: Cambridge University Press.

Ring, P.S., S.A. Lenway and M. Govekar (1990), 'Management of the political imperative in international business', Strategic Management Journal 11, 141-51.

Ronit, K. (2001), 'Institutions of private authority in global governance: Linking territorial forms of self-regulation', Administration \& Society, 33, 555.

Ronit, K. and V. Schneider (1999), 'Global governance through private organizations', Governance: An International Journal of Policy and Administration, 12 (3), 243-66.

Rose, N. and P. Miller (1992), 'Political power beyond the state: Problematics of government', The British Journal of Sociology, 43 (2), 173-205.

Rubio, F.D. and P. Baert (eds) (2012), The Politics of Knowledge, London: Routledge.

Ruggie, J. (2004), 'Reconstituting the global public domain: Issues, actors and practices', European Journal of International Relations, 10, 449.

Sassen, S. (2006), Territory, Authority, Rights: From Medieval to Global Assemblages, Princeton: Princeton University Press. 
Scherer, A.G. and G. Palazzo (2011), 'The new political role of business in a globalised world: A review of a new perspective on CSR and its implications for the firm, governance and democracy', Journal of Management Studies, 48, 899-931.

Sassen, S. (2003), 'Globalization or denationalization?' Review of International Political Economy, 10, 1-22.

Scholte, J.A. (2005), 'Civil society and democracy', in R. Wilkinson (ed) The Global Governance Reader, London: Routledge, pp. 322-40.

Scholte, J.A. (2004), Globalization and Governance: From Statism to Poly-Centrism, CSGR Working Paper No.130/04.

Scholte, J.A. (2000), Globalization: A Critical Introduction, Basingstoke: Palgrave Macmillan.

Scholte, J.A. (1996), 'Beyond the buzzword: Towards a critical theory of globalization', Globalization: Theory and Practice, 43-57.

Shore, C., S. Wright and D. Però (eds) (2011), Policy Worlds: Anthropology and the Analysis of Contemporary Power, New York \& Oxford: Berghahn Books.

Sklair, L. (2001), The Transnational Capitalist Class, Oxford: Blackwell.

Smith, J.A. (1991), The Idea Brokers: Think Tanks And The Rise Of The New Policy Elite, New York, NY: The Free Press.

Spencer, J. (2007), Anthropology, Politics and the State: Democracy and Violence in South Asia, Edinburgh: University of Edinburgh.

Spiller, P.T. (1990), 'Politicians, interest groups, and regulators: A multipleprincipals agency theory of regulation, or "let them be bribed", Journal of Law and Economics, 33, 65-101.

Stone, D. (2012), 'Transfer and translation of policy', Policy Studies, 33 (6), 483-99.

Stone, D. (2008), 'Global public policy, transnational policy communities and their networks', Policy Studies Journal, 36 (1), 19-38.

Stone, Diane (2002), 'Global knowledge and advocacy networks', Global Networks, $2(1), 1-11$.

Stone, D. (2000), 'Introduction: The changing think tank landscape', Global Society, 14 (2), 149-52.

Svedberg Helgesson, K. and U. Mörth (2013), 'Introduction: The political role of corporate citizens', in K. Svedberg Helgesson and U. Mörth (eds), The Political Role of Corporate Citizens: An Interdisciplinary Approach, Basingstoke: Palgrave Macmillan.

Vallentin, S. and D. Murillo (2012), 'Governmentality and the politics of CSR', Organization, 19 (6), 825-43.

Wedel, J. et al. (2005), 'Towards an anthropology of public policy', Annals of the American Academy of Political and Social Science, 600 (1), 30-51.

West, H.G. and T. Sanders (2003), 'Introduction: Power revealed and concealed in the new world order', in Harry G. West and Todd Sanders (eds), Transparency and Conspiracy: Ethnographies of Suspicion in the New World Order, Durham: Duke University Press, pp. 1-37.

Woll, C. (2008), Firm Interests: How Governments Shape Business Lobbying on Global Trade, Cornell: Cornell University Studies.

Yoffie, D. and S. Bergenstein (1985), 'Creating political advantage: The rise of the political entrepreneur', California Management Review, 28, 124-39. 